\title{
Pro-Poor Tourism as Approach to Alleviating Poverty: Experiences and Critical Issues
}

\author{
Rui Zhou ${ }^{1,2,3}$, Lin-sheng Zhong ${ }^{1}$, Sheng-rui Zhang ${ }^{1,3}$, Xiang-yuan Ma ${ }^{1,3}$ \\ ${ }^{1}$ Institute of Geographic Sciences and Natural Resources Research, CAS \\ ${ }^{2}$ College of History and Tourism Culture, Inner Mongolia University, 3University of Chinese Academy of Sciences \\ catherine-rui@hotmail.comzhongls@igsnrr.ac.cn
}

\begin{abstract}
By analyzing 2 pro-poor tourism projects from South Africa ,the main aim of this paper is to obtain similarities and draw experiences to identify key issues which can be adopted in practices for others. Although the type of pro-poor tourism project is impossible to be restricted to a single model, key pro-poor tourism issues could be adopted for the poor areas where tourism is capable to be developed. strategy

Index Terms - pro-poor tourism; South Africa;experience;

1. Introduction

Pro-poor tourism (PPT) is defined as tourism that generates net benefits for the poor. Poverty reduction is not usually at the heart of the tourism agenda; however, research and consultation on the interrelationship of tourism and poverty demonstrate that the tourism sector has become apparently to be immense potential to help the global antipoverty flight [1]. As Tourism and Poverty Alleviation announces that there is a global recognition that tourism could contribute more to development strategies for poor countries
\end{abstract}

as tourism shows up as a focal sector in $90 \%$ of Poverty Reduction Strategy Paper (PSRP), a combination of tourism industry and the poor population is significantly and urgently required to achieve the goal of poverty reduction[2].The main aim of this paper is to obtain similarities and draw experiences from the current 2 PPT projects cases in South Africa and to identify some key issues which can be adopted in practices for others.

\section{Common Strategies of two PPT Projects in South Africa}

The various PPT strategies are categorizes into three main types (see Table1): expanding economic benefits for the poor; addressing livelihood impacts; and developing pro-poor policies, processes and partnerships [3]. Although the specific actions to each type ranges from top-down to government-led approaches owning to the diversity of focuses and contexts (see Table2), the ultimate aim is on tilting tourism towards unlocking more opportunities for the poor [4].

TABLE 1 PPT strategies

\begin{tabular}{|l|l|l|}
\hline \multicolumn{1}{|c|}{ Expanding economic benefits } & \multicolumn{1}{|c|}{ Addressing livelihood impacts } & \multicolumn{1}{c|}{ Developing participation/partnership } \\
\hline Boost local employment; & Capacity building, training; & Create more supportive policy/planning framework; \\
Boost local enterprise opportunities; & Mitigate environmental impacts; & Increase participation of the poor in decision-making \\
Create collective income; & Address competing use of natural resources; & Build pro-poor partnerships with private sector; \\
& Improve social, cultural impacts; & Increase flows of information communication \\
& Increase local access to infrastructure and services; & \\
\hline
\end{tabular}

Source: C.Ashley, 2002

TABLE 2 Strategies and actions in each case

\begin{tabular}{|l|l|l|}
\hline & Maputaland & Makuleke \\
\hline Business opportunities & Yes but guntapped potential & SME opportunities \\
\hline Employment opportunities & local employment & incorporated into \\
\hline Collective benefits & & investment criteria \\
\hline Capacity building \& empowerment & Equity stake & allow communal and individual benefits \\
\hline Environmental impacts & & business development and land reform \\
\hline Social/ cultural impacts & & \\
\hline Policy\& planning framework & & \\
\hline Participation & Attempt to get cultural heritage tourism & \\
\hline Private sector partnerships & & Replicate new approaches \\
\hline & Tripartite partnership & Communities' empowerment \\
\hline & & Leverage private sector \\
\hline
\end{tabular}

Notes: blanks does not necessarily imply lack of activity in this area, simply that this is not a key focus in cases.

Source: C.Ashley, D.Roe and H.Goodwin,2001 
The Spatial Development Initiative (SDI) is a regional development project oriented to the promotion of industrial, commercial and tertiary sector activities, and expansion of employment opportunities [5]. The key objectives of SDI are to generate sustainable economic growth and development in relatively underdeveloped areas, to maximize the extent to which private sector investment and lending can be mobilized into the SDI area, and to exploit the spin-off opportunities that arise from the development of small, medium and microsized industries and the empowerment of the local communities [6]. Maputaland is a growing tourism destination in South Africa, with the tourism segments including coastal tourism and photographic safari tourism (see Figure1). When firstly introduced to Maputaland, SDI envisaged that the rural people would become the primary beneficiaries in a number of ways [7]. For this reason, the objectives of PPT project which falls under the SDI, intent to establish a range of policies to employ local people; encouraging local provision of services; enhancing the community share in the partnership [8]. Wilderness Safaris (WS) operating at the Maputaland comprising two lodges, the Rocktail Bay Lodge and the Ndumu Lodge, is representatives the responsible organization of PPT initiatives, the efforts of which in the region has increased the benefits to the community partners and diversified the tourism service.

The Community Public Private Partnership Programme (CPPP) is originated from National investment programme to revitalise depressed rural economies through the linking of resource-rich communities with relevant state and private investors interested in the sustainable utilisation of natural assets [6]. It focuses on areas that underdeveloped but with significant tourism potential areas of South Africa, aiming to facilitate new tourism investment and promote partnerships between communities, the private sector [2]. Makuleke is located in the Northern Province of South Africa, an area of high conservation value and with significant tourism potential (see Figure1). It is a significant tour destination for both local and international tourists. The PPT initiative arose as a consequence of the land restitution process, with a condition that the land would continue to be utilized for conservation purposes. Makuleke Community Property Association (CPA) is established. As a landowner, CPA starts the Makuleke propoor tourism initiatives for the sake of income and employee opportunities for the Makuleke community. This project has receiveed support from various stakeholders, including CPPP programme, local company, and donor organization. It is even being used as a CPPP pilot project to develop policy and procedural guidelines for the implementation of similar community-based projects in South Africa.

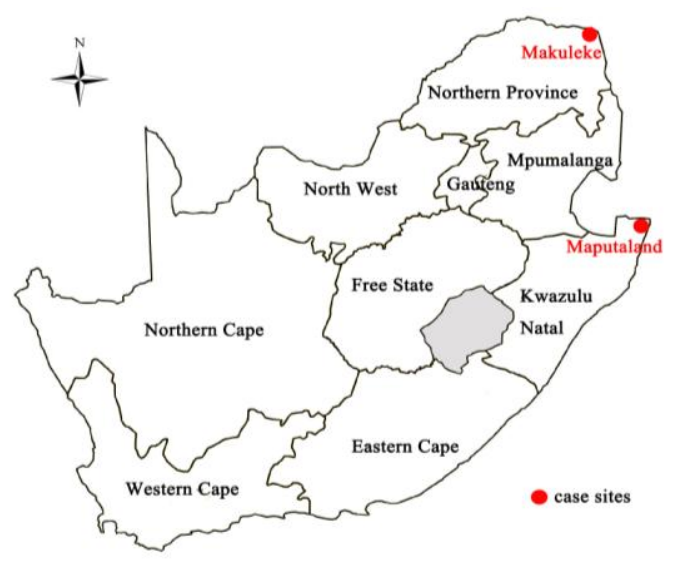

Fig 1 Orientation map of South Africa and case sites

\section{A. Expand business opportunities}

All PPT initiatives focus on economic benefits, with the expansion of business opportunities particular for enterprises and associations as a core area [5]. Expanding business opportunities is done mainly through offering support, training membership and developing markets. Assistances from representative organizations dramatically support the poor and their association to gain new skills and develop new products. By doing so, the poor can be involved in most actions as individual producers, employees, casual labours, and operators of micro and small enterprises [9]. For example, WS develop its unique cultural products to reinforce market share. Maputaland has a high population of sangomas who practice their art using the many herbal remedies available from the region's biodiverse ecosystem. This traditional dance and ceremony has been developed as a Sangomas Performance to cater for outer visitors. The special sangoma training school is established for cultivating interns and supplying materials for performance, and in turn, the money earned from performance allows keeping the training running [5].

\section{B. Generate Collective Income}

Collective income is generally used for community investment, rather than being distributed to households. Ways of doing it are respectively through leases, levies and equity stakes [10]. In terms of the equity share, there is obvious evidence on the structure of WS. As described above, WS is an equity holder in the lodge owner and lodge operating company based on a tripartite-contract relationship between the conservation authority and community. According to this contract, the operating funds are loans from Ithala Bank, another stakeholder in PPT project, and the community holds a $12.5 \%$ share of profits. Although to date the community has only received dividends from the Lodge Owning Company, the benefits community received has built its confidence in the initiative [11].

\section{Partnerships of Private Sector}

The private sectors acts as the investor, developer, and operator and thus assume a critical role in the alleviation of poverty [10]. Ashley, Roe and Goodwin (2000) stress that many poor can participate in tourism through activities in 
small firms such as selling food and crafts and supplying cultural services[12]. Involving with the private sectors has some advantages for they can do an enormous amount to create linkages with the local economy and drive local development. There are different ways to link up with the private sector, from formal to the casual. A legal partnership between a private company and local community has been established in the Maputaland, where the private sector is invited to build and operate tourism facilities on state-owned land, like WS. The private sector in Makuleke is encouraged to build links with local poor though it is still in a process of being invited by $\mathrm{CPA}$ to submit proposals for planning, designing, financing and constructing tourism facilities. Differently, the private sector in Namibia is the most influential in tourism development.

\section{Critical Issues Relevant to Pro-Poor Tourism}

\section{A. Design Tour Products to be Commercially Sustainable}

The core competitive capability of a tour destination leans on its tour products. Designing tour products should be based on the real market demands and sustainable consideration, meanwhile not sacrifice natural or cultural resources [13]. The commercial attractiveness, the real quality and marketing strategy are crucial elements of general tour products to sustain the competitive competence, let along those products from the poor regions. While the pro-poor tour products are to compete with other similar tourism products, the quality and reliability are essential. If the products and services are of sufficient quality, a higher price is possible to charge, and a very small increasing price will not lead to customers looking for alternative products [14].

Marketing is a third issue concerning the commercial sustainability. The expansion of tourism should be in line with market capacity so that it can serve as a dynamic catalyst of poverty elimination [15]. According to Peter Murphy (1985), each community or destination can develop its own special product mix, taking into account its resources, values, needs and preferences [1]. For example, WS lodges cannot compete with the major lodges and so turn to more special birdwatching activity.

\section{B. Capacity Building}

Experiences from above case studies show that PPT projects highly lean on a good deal of capacity building among communities to obtain assistance. According to WTO (2006), successful PPT often requires an integrated approach at the local level with capacity building and skills development, particularly focusing on community and SMMEs [16]. Ashley, Roe and Goodwin (2000) also mention that the local capacity is one key component to PPT, though it is closed link with the aim of enhancing business impacts [12]. Generally, capacity among the poor is noted in three distinct dimensions: increasing poor people's basic understanding of themselves and tourism industry; gaining business management skills, and empowering community organization, particularly for managing common resources and distributing benefits.

Apart from the adjustment of poor's concept and skills training, capacity building can be fulfilled through programme of the poor empowerment [17]. There is strong evidence in CPA, Makuleke. BEE performs its functions in transferring of ownership of equity, increasing control and influence in management of organizations. This initiative finally empowers the poor the engage effectively as organized communities in decision-making.

\section{Government Policy}

It is undoubtedly that the positive and supportive of policy framework working at destination, national and international levels will pave a way for carrying out PPT project. Responsive and effective legislation hence needs to plan in a participative manner, coordinating with all involved parties to encourage and support pro-poor tourism development [1]. This requires firstly government officials are aware of the essential links between tourism development and poverty reduction so that the national PPT strategies can be developed with the recognition that tourism is critical in improving the poor condition [18]. By doing so, given the leading role of government, it is possible for different stakeholders and sectors raise the awareness of the destination regarding to the complexity of tourism industry [19]. The land right and tenure seems to be a crucial obstacle for implementing PPT strategy in South Africa, and the government embodies a substantial change in policy by building on land reform. Where land remains in state control, government seeks to use planning gain, an approach for government and other stakeholder to control over allocation of concessions and to influence investors on behalf of the poor. However, the local and specific regulations should be in compliance with the national policy, otherwise they will confuse the objective and aims of entire PPT project and even present obstacles to poverty reduction [5]. On the other hand, the local regulation covering tourist activities, qualifications of workers or service standards will play functions in another field, where formal sectors lacking contacts and capital [20]. Moreover, the administrative structures need to be well organized to facilitate the adoption of the integrated approaches. Otherwise, the structure of conservation authority communities in Maputaland (WS) may block the way to propoor. This thus requires that various ministries and departments are willing to cooperate and support destination plans that bring together various ministerial and departmental concerns. However, even though the commitment of government is fulfilled, the lack of capacity for implementation can also weaken the efforts.

\section{Conclusions}

To summarize, tourism is a potential means to poverty eradication, and it particularly plays significant part in South Africa owning to the poverty conditions there [21]. There is no absolutely single model or form for pro-poor tourism development, however common strategies undertaken by South Africa including expanding business and employment opportunities and generating collective income are implemented. Three issues drawn from South Africa namely products designing, the capacity building, policy framework 
and the attitude of levels of governments are not only critical for PPT projects in Africa, but also applicable for other projects.

\section{References}

[1] Poverty Alleviation through Sustainable Tourism Development, United Nations, New York, United Nations 2003.

[2] K. Mahony and Van Zyl. Jurgens, "PPT Working Paper 2: Practical strategies for pro-poor tourism: case studies of Makuleke and Manyeleti tourism initiatives.. Overseas Development Institute (ODI), International Institute for Environment and Development (IIED) \& Centre for Responsible Tourism (CRT), 2001.

[3] N. Nicanor, "PPT Working Paper No.4: Practical strategies for pro-poor tourism: NACOBTA the Namibian case study," London: Overseas Development Institute (ODI), International Institute for Environment and Development (IIED) \&Centre for Responsible Tourism (CRT), 2001.

[4] Ashley, "PPT working paper 10: Methodology for pro-poor tourism case studies," London: Overseas Development Institute (ODI), International Institute for Environment and Development (IIED) \& Centre for Responsible Tourism (CRT), 2002.

[5] Ashley and D.Roe, "Making tourism work for the poor: strategies and challenges in southern Africa," Development Southern Africa, vol.8, no.2, pp. 61-82, 2002.

[6] South Africa Country Profile, United Nations, Johannesburg, United Nations Publication, 2002.

[7] T.Kape, "Clearing the found in the Spatial Development Initiatives (SDIs): analyzing "process" on South Africa's Wild Coast," Development Southern Africa, vol.18,no.3, pp. 279-293, 2001.

[8] Koch, G. de Beer and S. Elliffe, et al, "International perspectives on tourism-led development: some lessons for the SDIs," Development Southern Africa, vol.15, no.5, pp 907-915, 1998.

[9] C.Ashley, D.Roe and H.Goodwin, "Pro-Poor Tourism Report No.1: Propoor tourism strategies: making tourism work for the poor, a review of experience," London: Overseas Development Institute (ODI), International Institute for Environment and Development (IIED) \& Centre for Responsible Tourism (CRT), 2001.

[10]M.Carbone, "Sustainable tourism in developing countries: poverty alleviation participatory planning and ethical issues," The European Journal of Development Research, vol.13, no.3, pp.559-565, 2005.

[11]C.Poultney, A.Spenceley, "PPT Working Paper No.1: Practical strategies for pro-poor tourism: wilderness safaris South Africa: Rocktail Bay and Ndumu Lodge," London: Overseas Development Institute (ODI), International Institute for Environment and Development (IIED) \& Centre for Responsible Tourism (CRT), 2001.

[12] Meyer, "PPT Working Paper No.17: The UK outbound tour operating industry and implications for Pro-poor tourism," London: Overseas Development Institute (ODI), International Institute for Environment and Development (IIED) \& Centre for Responsible Tourism (CRT), 2003.

[13] Tourism's Potential as Sustainable Development Strategy, World Tourism Organization, Madrid: WTO, 2005.

[14] Poverty Alleviation through Tourism: A Compilation of Good Practice, World Tourism Organization, Madrid: WTO, 2006.

[15]C.Ashley, "How can governments boost the local economic impacts of tourism? Options and tools," London: Overseas Development Institute, 2006.

[16]P.Jordan, "Enhancing the economic benefits of tourism for local communities and poverty," Madrid: WTO, 2002.

[17]D.Hall and F.Brown, "Tourism and welfare: ethics, responsibility and sustained well-Being," in Tourism and Inequality: Problems and Prospects, 2006, pp.106-131.

[18] X.Cattarinich, "PPT Working Paper No.8: Pro-poor tourism initiatives in developing countries: analysis of secondary case studies," London: Overseas Development Institute (ODI), International Institute for Environment and Development (IIED) \& Centre for Responsible Tourism (CRT), 2001.

[19]C.Ashley, "Working Paper 257: Facilitating pro-poor tourism with the private sector: lessons learned from "Pro-poor tourism pilots in Southern Africa". Overseas Development Institute (ODI), International Institute for Environment and Development (IIED) \& Centre for Responsible Tourism (CRT), 2005.

[20]C.Ashley, C. Boyd and H.Goodwin, "Pro-poor tourism: putting poverty at the heart of the tourism agenda," Natural Resource Perspective, no.51. London: Overseas Development Institution (ODI), 2000.

[21]C.Jonsson, "Understanding the Dimensions of Pro-Poor Tourism," Tourism Geographies, vol.14, no.2, 2012 